\title{
Article
}

\section{The Motor Impact of the Static Balance in the Up Plank Position on Three Different Balls in Physical Activities of Physical Education Students}

\author{
Dana Badau 1(D), Adela Badau 1,*(D), Gabriel Manolache ${ }^{2}$, Mircea Ion Ene ${ }^{2}$, Adriana Neofit ${ }^{2}$, Vlad Teodor Grosu ${ }^{3}$, \\ Virgil Tudor ${ }^{4}$ (D), Radu Sasu ${ }^{1}$, Raluca Moraru ${ }^{5, *}$ and Liviu Moraru ${ }^{5}$
}

1 Faculty of Sciences and Letters, "George Emil Palade" University of Medicine, Pharmacy, Sciences and Technology, 540142 Targu Mures, Romania; dana.badau@umfst.ro (D.B.); cristianss4@hotmail.com (R.S.)

2 Faculty of Physical Education and Sport, "Dunarea de Jos" University, 800003 Galati, Romania; gabriel.manolache@ugal.ro (G.M.); mircea.ene@ugal.ro (M.I.E.); adriana.neofit@ugal.ro (A.N.)

3 Faculty of Automotive Mechatronics and Mechanical Engineering, Technical University of Cluj-Napoca, 400114 Cluj-Napoca, Romania; vlad.grosu@mdm.utcluj.ro

4 Faculty of Physical Education and Sports, National University of Physical Education and Sports, 060057 Bucharest, Romania; virgiltro@yahoo.com

5 Faculty of Medicine, "George Emil Palade" University of Medicine, Pharmacy, Sciences and Technology, 540142 Targu Mures, Romania; liviu.moraru@umfst.ro

* Correspondence: adela.badau@umfst.ro (A.B.); raluca.moraru@umfst.ro (R.M.); Tel.: +40-723-19-83-91 (A.B.); +40-736-42-00-24 (R.M.)

Citation: Badau, D.; Badau, A.; Manolache, G.; Ene, M.I.; Neofit, A.; Grosu, V.T.; Tudor, V.; Sasu, R.; Moraru, R.; Moraru, L. The Motor Impact of the Static Balance in the Up Plank Position on Three Different Balls in Physical Activities of Physical Education Students. Int. J. Environ. Res. Public Health 2021, 18, 2043. https://doi.org/10.3390/ ijerph18042043

Academic Editors: Wi-Young So and Palma Chillón Garzón

Received: 20 January 2021

Accepted: 15 February 2021

Published: 19 February 2021

Publisher's Note: MDPI stays neutral with regard to jurisdictional clai$\mathrm{ms}$ in published maps and institutional affiliations.

Copyright: (C) 2021 by the authors. Licensee MDPI, Basel, Switzerland. This article is an open access article distributed under the terms and conditions of the Creative Commons Attribution (CC BY) license (https:// creativecommons.org/licenses/by/ $4.0 /)$.

\begin{abstract}
The present study aimed to assess the capacity of stability and motor impact in the development of the balance of student athletes by reducing the support surface on the ball in the up plank position, by using three categories of balls of equal size, but with different elasticity and weight. In this study, the second aim was to investigate the differences in maintaining static balance, on different balls, between those who are practicing individual sports or team sports. The total study sample include 48 students, active athletes ( $45.8 \%$ of individual sports and $54.2 \%$ of team sports), age $\mathrm{X} \pm \mathrm{SD} 18.74 \pm 1.94$ years. The research included two test sessions (initial and final) applied in two stages. The static balance tests were performed by measuring the time maintaining the up plank position with two and three points of support on the three balls, with different characteristics of elasticity and ranges of deformation: medical ball, handball ball and fitness ball. The results of the study showed that the superior initial and final results were recorded on the fitness ball, and the inferior results on the medicine ball. The upper difference was recorded at the up plank position with two support points (arms, legs) on the fitness ball, at $4980 \mathrm{~s}$, and the lowest in the same test on the medical ball, at $3420 \mathrm{~s}$. The largest difference was recorded at the up plank position with three support points on the handball ball, at $7.082 \mathrm{~s}$, and the lowest in the same test on the medical ball, at $3.093 \mathrm{~s}$. The subjects of the study perceived that the most difficult position to execute was the up plank position on the medical ball with two support points, with $43.8 \%$, and the easiest stability was registered in the up plank position on the fitness ball with three points of support, of 37.5\%. The relevance of the research results from the possibility of using different balls in conditions of positioning and body posture with a diminished support base in order to improve physical fitness.
\end{abstract}

Keywords: static balance; plastic balls; up plank position; physical fitness; isometric muscle contraction; health

\section{Introduction}

In the practice of physical activities, the use of balls of different sizes and with different elastic characteristics is common, and the study of the impact on the components of motor capacity is manifested as a dynamic trend of physical activities, especially in the last decade. The innovative trends of the last decade regarding the design and technologies of different 
devices and plastic material have largely influenced fields such as medicine, education and sports [1]. Numerous studies have highlighted the fact that the technical characteristics and properties of different sport equipment and materials greatly influence motor capacity in order to optimize physical fitness [2,3].

An important component of physical fitness is balance, which manifests in two forms: statically and dynamically $[4,5]$. Static balance is an important component and determinant of the body balance and implicit physical fitness. The level of development of body balance is conditioning the development of the other physical skills, which are influenced by the good functionality of the vestibular system [6,7], the central nervous system and the plasticity of the cerebral cortex [8-10], the health status [11] and by the level of physical condition and the baggage of individual sports skills [12-14]. In practical activity, for the development of body balance, various sports materials are used, with different technical characteristics in terms of shape, elasticity, deformation, dimensions, etc. Studies show that the smaller and more unstable the support surface, the more adequate the motor and postural control must be [15-17].

Balls of different compositions, with different characteristics of elasticity and adhesion, as well as with different sizes and weights, are used in the practice of physical activities and in therapy in order to improve the static and dynamic body balance [2-4], and the proprioception and strength [18-20], as well as in neuro-muscular and functional rehabilitation [21-24]. The balls that are used in physical activities are made by a specific technology from materials such as butadiene rubber, from polyurethane and polyvinyl chloride. In our study, we used three types of balls, namely: medical balls (butadiene rubber), handball balls (polyurethane) and fitness ball (polyvinyl chloride). Butadiene rubber is an elastic polymer resulting from the polymerization of butadiene, which is the most important monomer and which is characterized by the following properties: good insulator, low elasticity, good water resistance and a remarkable abrasion resistance $[25,26]$. Polyurethane (PU) balls, a composite material, versatile, stronger and more resistant than PVC, are the closest in terms of technical characteristics to natural leather, with the following properties: high wear resistance, water-repellent effect, softness at low temperatures, and good elasticity allowing for the maintenance of sphericity and good controllability of the ball $[27,28]$. Polyvinyl chloride (PVC) is a versatile polymer with varied applicability, being a very durable material, with high strength, resistance to climate change and good geometric stability [29]. The research on the effects of the use of different types of balls on the parameters of static balance and general force focused on the development of throwing force [30] and improvement in technical sports skills [31,32].

Investigating the up plank position under various conditions of balance and strength, using fitness equipment with specific dimensions and technical characteristics, facilitates the understanding of motor impact by facilitating the extension of its applicability in physical activities and therapy [33-36]. The up plank position is a complex movement that requires maintaining balance in conditions of isometric muscle contraction. Anatomical analysis of maintaining an up plank position highlights the activation of the following muscles: biceps brachii, triceps brachii, deltoideus, brachialis, latissimus dorsi, serratus anterior, obliquus internus, vastus lateralis, rectus femoris and tibialis anterior, as well as articulations: scapulo-humeral, humero-radio-ulnar, radio-carpal, inter-carpal, coxofemural, femuro-tibial, tibio-talar and inter-tarsal [37,38]. The up plank position is used in fitness activities in order to improve body balance and general muscle strength, aiming at the development and rehabilitation of the vestibular system and the human muscular system. The up plank position is also used as a fitness test to assess muscle strength and endurance [39-42]. In our study, we want to give a new use to this plank up test in order to evaluate the ability to maintain static balance on small and unstable surfaces.

The study focused on highlighting the capacity of stability and motor impact in the development of balance and implicit of the general strength by reducing the support surface on the ball in the up plank position, by using three categories of balls of equal size, but of different elasticity and weight. It is important to understand how the use of different 
fitness equipment, with different technical characteristics, influences the components of physical fitness in physical activities.

In this context, the first aim of the study was to evaluate the stable equilibrium capacity in the top board position with two and three support points in relation to the characteristics and technical properties of the use of three types of ball with the same shape and circumference, with different elasticities and weights, namely: medical ball, handball and fitness ball. Because the research sample consisted of active athletes customized according to the type of sport, the second objective of the study was to investigate the differences between those who practice individual sports and those who practice team sports aiming to maintain static balance on the three balls selected for the study.

\section{Materials and Methods}

\subsection{Participants}

The study included a sample of volunteer students from the University of Medicine, Pharmacy, Science and Technology "George Emil Palade" of Targu Mures, Romania. All participants were informed about the details of the study; all participants were anonymous and voluntary. The inclusion criteria in the study were: active student in the Physical Education and Sports program, active athlete, good health, age under 20. We selected only male students because the number of female students in the Physical Education and Sports program is very small, $\leq 10$, in accordance with the inclusion criteria. The sample included 48 male students, 22 students of individual sports (45.8\%), 26 students of team sports $(54.2 \%)$, with a mean age $X \pm S D 18.74 \pm 1.94$ years; mean height $X \pm S D 178.39 \pm 6.60 \mathrm{~cm}$; average weight $X \pm S D 75.35 \pm 6.56 \mathrm{~kg}$.

\subsection{Procedure}

The study took place between 28 September and 29 November 2020. The study was conducted in accordance with the Declaration of Helsinki, and the protocol was approved by the the Review Board of Movement Sciences Department, "George Emil Palade" University of Medicine, Pharmacy, Sciences and Technology of Targu Mures, Romania (resolution no. 36/23/05/2019). The research included two test sessions applied in two stages: initial testing and final testing. The initial testing was applied at the beginning of the experiment between 28 September 28 and 30 September 2020, and the final testing between 27 and 29 November 2020.

\subsection{Program of the Static Balance}

Between the initial and final tests, the independent variable consisting of a program provided online including balance exercises and the development of general muscle strength was applied, three times per week, with $20 \mathrm{~min}$ per session. The balance exercise program included free exercises with a diminished support surface and stable balance exercises on different balls with different sizes and elasticities: medicine balls, handball balls, fitness balls, boss ball, swiss fitness ball. The study participants were monitored online via the google meets platform; the exercise program was performed at home. Before each training session, participants received the daily descriptive and imaging program including a description of the exercises, the dosage, the nature and duration of the break between the exercise evenings, and the sports materials used. The training sessions, as well as the monitoring of the correctness of the execution, were carried out under the verbal and video guidance of the study experts.

\subsection{Measures}

We selected the plank up fitness test on unstable round surfaces for this study. The plank up test has been used in numerous studies to measure global core muscle function, with a focus on balance capacity, endurance and muscle strength [40-42]. The static balance tests were performed by measuring the time spent maintaining the up plank position with two and three points of support on the three balls: the medical rubber ball, the synthetic 
leather handball ball and the PVC fitness ball. The timer is turned on (measuring the time in seconds) from the moment when the subject is in the correct position, maintaining balance, and it is stopped when the subject is unbalanced and is touching the ground. For this study, we used three different kind of balls, with variable characteristics of elasticity. Ball materials used in the study are as follows: ballasted medical balls made of $100.00 \%$ butadiene rubber, weight $1 \mathrm{~kg}$, diameter $19 \mathrm{~cm}$, recommended pressure 0.3-0.5 bar; handball balls Select size 3 made of polyurethane (ultragrippy PU synthetic leather, sewn by hand), with latex chamber, weight $0.475 \mathrm{~kg}$, diameter $19 \mathrm{~cm}$, recommended pressure $0.3-0.5 \mathrm{bar}$; fitness ball made PVC, weight $0.340 \mathrm{~kg}$, diameter $19 \mathrm{~cm}$, recommended pressure $0.3-0.5$ bar.

\subsection{Research Instruments}

The tests took place in the gym under the direct organization and evaluation of the experts from the study. The tests had the following chronology: session 1-testing the static balance in the up plank position on the medical ball with two support points (arms-legs), then a 30 min break followed by testing the static balance in the up plank position on the handball ball with two support points (arms-legs), then a 30 min break followed by testing the static balance in the up plank position on the fitness ball with two support points (arms-legs); session 2-held 2 days after the first session, as follows: testing the static balance in the up plank position on the medicine ball with three support points (right arm-left arm-legs), then a 30 min break followed by testing the static balance in the up plank position on handball ball with three points of support (left arm—right arm—legs), then a 30 min break followed by testing the static balance in the up plank position on fitness ball with three points of support (left arm—right arm—legs).

\subsection{Data Analysis}

Statistical analysis of the plank up test results for evaluating the static balance on round, elastic and unstable surfaces were processed with the program SPSS 21., calculating the following basical statistical indicators: arithmetic mean $(\mathrm{X})$, standard deviation (SD), Min.-Minimum, Max.-Maximum, XD—differences between arithmetic averages, SDDdifferences between standard deviations. The normality of distributions was assessed by using the Shapiro-Wilk test (S-W). Differences between groups were analysed with Student's $t$-test. To detect the true effect, we calculated the statistical power (SP) for the repeated measures and the chosen level required was at least 0.8 . Selected significance level of probability was $p \leq 0.05$.

\section{Results}

The analysis of the results in Table 1 from the motor evaluation shows that between the balance tests on the three balls with 2 and 3 support points, the superior initial and final results were recorded on the fitness ball, and the inferior results on the medicine ball. The comparative analysis of the results shows a statistically significant power; the registered values were higher than the threshold of 0.80 . All results were statistically significant for $p \leq 0.05$. All the data were normally distributed; the null hypothesis is rejected.

The difference analyses between initial and final tests for maintaining the balance test on the three types of balls in the up plank position for the whole sample were statistically significant for both tests and on all three balls (Table 2, Figure 1, Figure 2). The higher difference was recorded at the up plank position with two support points (arms, legs) on the fitness ball DX 4.980, and the lowest at the same test on the medical ball DX 3.420. The largest difference was recorded at the up plank position with three support points (right arm, left arm, legs) on the handball ball DX 7.082, and the lowest at the same test on the medical ball DX 3.093. 
Table 1. Differences between initial and final tests of physical tests of maintaining balance on the three types of ball in the up plank position—for whole sample.

\begin{tabular}{|c|c|c|c|c|c|c|c|}
\hline Positions & Types of Balls & Tests & $X(s)$ & SD & Min. (s) & $\operatorname{Max}(s)$ & S-W \\
\hline \multirow{6}{*}{$\begin{array}{l}\text { Up plank position with } 2 \text { support } \\
\text { points (arms, legs) }\end{array}$} & \multirow{2}{*}{ on the medical ball } & $\mathrm{Ti}$ & 30.068 & 11.233 & 8.62 & 56.12 & 0.817 \\
\hline & & $\mathrm{Tf}$ & 33.488 & 15.840 & 10.62 & 91.71 & 0.893 \\
\hline & \multirow{2}{*}{ on the handball ball } & $\mathrm{Ti}$ & 32.601 & 16.957 & 9.27 & 77.45 & 0.855 \\
\hline & & Tf & 36.338 & 21.678 & 10.62 & 85.32 & 0.891 \\
\hline & \multirow{2}{*}{ on the fitness ball } & $\mathrm{Ti}$ & 49.210 & 26.737 & 15.11 & 98.27 & 0.907 \\
\hline & & Tf & 54.190 & 33.207 & 18.58 & 120.27 & 0.875 \\
\hline \multirow{6}{*}{$\begin{array}{l}\text { Up plank position with } 3 \text { support } \\
\text { points (right arm, left arm, legs) }\end{array}$} & \multirow{2}{*}{ on the medical ball } & $\mathrm{Ti}$ & 51.232 & 12.429 & 31.12 & 75.13 & 0.907 \\
\hline & & $\mathrm{Tf}$ & 54.325 & 13.485 & 34.59 & 84.59 & 0.893 \\
\hline & \multirow{2}{*}{ on the handball ball } & $\mathrm{Ti}$ & 71.618 & 30.499 & 28.44 & 132.12 & 0.869 \\
\hline & & $\mathrm{Tf}$ & 78.701 & 35.024 & 34.65 & 148.60 & 0.875 \\
\hline & \multirow{2}{*}{ on the fitness ball } & $\mathrm{Ti}$ & 87.000 & 35.303 & 34.78 & 156.13 & 0.808 \\
\hline & & Tf & 91.839 & 40.778 & 48.92 & 174.25 & 0.821 \\
\hline
\end{tabular}

X—Mean, SD—Std. Deviation, Min.—Minimum, Max.-Maximum, S-W—Shapiro-Wilk test, Ti—initial test, Tf-final test.

Table 2. Descriptive statistics of difference analyses between initial and final tests for maintaining balance test on the three types of balls in the up plank position-for whole sample.

\begin{tabular}{|c|c|c|c|c|c|c|c|c|}
\hline Positions & Types of Balls & Tests & $X$ (sec.) & DX (sec.) & DSD & $\mathbf{t}$ & $\mathbf{p}$ & SP \\
\hline \multirow{3}{*}{$\begin{array}{l}\text { Up plank position with } 2 \text { support } \\
\text { points (arms, legs) }\end{array}$} & on the medical ball & $\begin{array}{l}\mathrm{Ti} \\
\mathrm{Tf}\end{array}$ & $\begin{array}{l}30.068 \\
33.488\end{array}$ & -3.420 & 10.963 & -2.161 & 0.036 & 0.826 \\
\hline & on the handball ball & $\begin{array}{l}\mathrm{Ti} \\
\mathrm{Tf}\end{array}$ & $\begin{array}{l}32.601 \\
36.338\end{array}$ & -3.737 & 11.537 & -2.244 & 0.030 & 0.815 \\
\hline & on the fitness ball & $\begin{array}{l}\mathrm{Ti} \\
\mathrm{Tf}\end{array}$ & $\begin{array}{l}49.210 \\
54.190\end{array}$ & -4.980 & 16.411 & -2.103 & 0.041 & 0.897 \\
\hline \multirow{3}{*}{$\begin{array}{l}\text { Up plank position with } 3 \text { support } \\
\text { points (right arm, left arm, legs) }\end{array}$} & on the medical ball & $\begin{array}{l}\mathrm{Ti} \\
\mathrm{Tf}\end{array}$ & $\begin{array}{l}51.232 \\
54.325\end{array}$ & -3.093 & 9.6511 & -2.220 & 0.031 & 0.882 \\
\hline & on the handball ball & $\begin{array}{l}\mathrm{Ti} \\
\mathrm{Tf}\end{array}$ & $\begin{array}{l}71.618 \\
78.701\end{array}$ & -7.082 & 19.811 & -2.477 & 0.017 & 0.873 \\
\hline & on the fitness ball & $\begin{array}{l}\mathrm{Ti} \\
\mathrm{Tf}\end{array}$ & $\begin{array}{l}87.000 \\
91.839\end{array}$ & -4.839 & 14.737 & -2.275 & 0.028 & 0.849 \\
\hline
\end{tabular}

X-Mean, DX—differences of mean, DSD—differences of Std. Deviation, $t$-value of Student test, SP—statistical power, p-level of probability, Ti-initial test, $\mathrm{Tf}-$ final test.

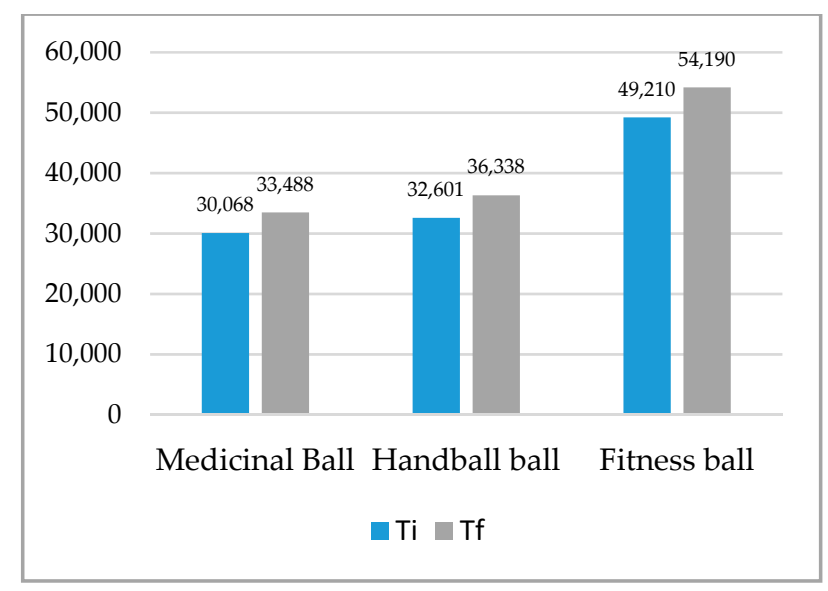

Figure 1. Mean of plank up test with 2 support points (arms, legs). Ti-initial test; Tf—final test. 


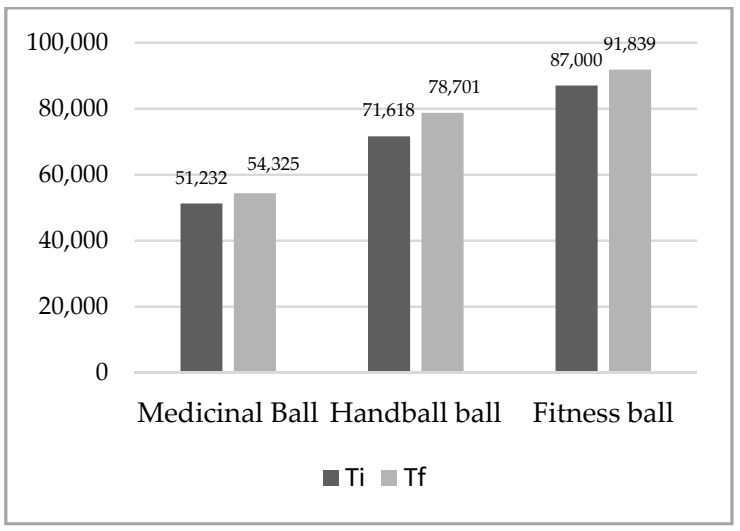

Figure 2. Mean of plank up test with 3 support points (arms, legs).

The analysis of the results in Table 3, Figures 3-6, shows that the superior results were recorded in both tests on the fitness ball, and the inferior results were shown on the medicine ball. In the individual sports group, the highest value was recorded in the final test in the up plank position test with three support points (right arm, left arm, legs) on the fitness ball 93.690, and the lowest in the initial test in the up test plank position with three support points (right arm, left arm, legs) on the fitness ball 28.379. The analysis of the team sports group shows that the highest value was recorded at the final test in the up plank position test with three support points (right arm, left arm, legs) on the fitness ball 90.400, and the lowest at the initial test at the test up plank position with three support points (right arm, left arm, legs) on the fitness ball 31.382. The distribution of the results was normal, according to the S-W results, which ranged between 0.795 and 0.923 . All results in both initial and final tests for both groups were statistically significant.

Table 3. Differences between initial and final tests of physical tests of maintaining balance on the three types of balls in the up plank position-individual sports group and team sports group.

\begin{tabular}{|c|c|c|c|c|c|c|c|c|}
\hline Groups & Positions & Types of Balls & Tests & $X(s)$ & SD & Min. (s) & $\operatorname{Max}(s)$ & S-W \\
\hline \multirow{12}{*}{$\begin{array}{l}\text { Individual sports } \\
\qquad(22 \mathrm{n})\end{array}$} & \multirow{6}{*}{$\begin{array}{l}\text { Up plank position with } \\
2 \text { support points } \\
\text { (arms, legs) }\end{array}$} & \multirow[b]{2}{*}{ on the medical ball } & $\mathrm{Ti}$ & 28.379 & 10.844 & 8.62 & 41.63 & 0.897 \\
\hline & & & $\mathrm{Tf}$ & 34.768 & 19.569 & 10.62 & 91.71 & 0.892 \\
\hline & & \multirow{2}{*}{ on the handball ball } & $\mathrm{Ti}$ & 31.262 & 12.360 & 10.62 & 50.87 & 0.866 \\
\hline & & & $\mathrm{Tf}$ & 36.976 & 21.496 & 10.62 & 85.32 & 0.872 \\
\hline & & \multirow{2}{*}{ on the fitness ball } & $\mathrm{Ti}$ & 48.058 & 24.745 & 15.11 & 91.71 & 0.903 \\
\hline & & & Tf & 53.223 & 32.488 & 18.58 & 120.27 & 0.923 \\
\hline & \multirow{6}{*}{$\begin{array}{c}\text { Up plank position with } \\
3 \text { support points (right arm, } \\
\text { left arm, legs) }\end{array}$} & \multirow[b]{2}{*}{ on the medical ball } & $\mathrm{Ti}$ & 54.830 & 12.726 & 31.12 & 75.13 & 0.893 \\
\hline & & & $\mathrm{Tf}$ & 56.186 & 12.632 & 34.59 & 75.13 & 0.914 \\
\hline & & \multirow{2}{*}{ on the handball ball } & $\mathrm{Ti}$ & 76.162 & 30.098 & 34.65 & 118.60 & 0.795 \\
\hline & & & $\mathrm{Tf}$ & 78.819 & 38.531 & 34.65 & 148.60 & 0.807 \\
\hline & & \multirow{2}{*}{ on the fitness ball } & $\mathrm{Ti}$ & 84.920 & 33.577 & 34.78 & 125.13 & 0.893 \\
\hline & & & Tf & 93.690 & 41.973 & 48.92 & 174.25 & 0.869 \\
\hline \multirow{12}{*}{$\begin{array}{l}\text { Team sports } \\
\qquad(26 \mathrm{n})\end{array}$} & \multirow{6}{*}{$\begin{array}{l}\text { Up plank position with } \\
2 \text { support points } \\
\text { (arms, legs) }\end{array}$} & \multirow{2}{*}{ on the medical ball } & $\mathrm{Ti}$ & 31.382 & 11.555 & 10.62 & 56.12 & 0.875 \\
\hline & & & $\mathrm{Tf}$ & 32.493 & 12.517 & 10.62 & 56.97 & 0.808 \\
\hline & & \multirow{2}{*}{ on the handball ball } & $\mathrm{Ti}$ & 33.642 & 19.992 & 9.27 & 77.45 & 0.821 \\
\hline & & & Tf & 35.841 & 22.214 & 10.62 & 85.32 & 0.817 \\
\hline & & \multirow{2}{*}{ on the fitness ball } & $\mathrm{Ti}$ & 50.106 & 28.623 & 18.58 & 98.27 & 0.866 \\
\hline & & & Tf & 54.943 & 34.353 & 18.58 & 120.27 & 0.872 \\
\hline & \multirow{6}{*}{$\begin{array}{c}\text { Up plank position with } \\
3 \text { support points (right arm, } \\
\text { left arm, legs) }\end{array}$} & \multirow{2}{*}{ on the medical ball } & $\mathrm{Ti}$ & 48.433 & 11.666 & 32.88 & 70.20 & 0.819 \\
\hline & & & $\mathrm{Tf}$ & 52.877 & 14.178 & 34.65 & 84.59 & 0.816 \\
\hline & & \multirow{2}{*}{ on the handball ball } & $\mathrm{Ti}$ & 68.084 & 30.903 & 28.44 & 132.12 & 0.871 \\
\hline & & & $\mathrm{Tf}$ & 78.609 & 32.793 & 34.65 & 132.02 & 0.869 \\
\hline & & \multirow{2}{*}{ on the fitness ball } & $\mathrm{Ti}$ & 88.618 & 37.141 & 48.92 & 156.13 & 0.875 \\
\hline & & & Tf & 90.400 & 40.569 & 48.92 & 174.25 & 0.866 \\
\hline
\end{tabular}

X-Mean, SD—Std. Deviation, Min.—Minimum, Max.—Maximum, S-W—Shapiro-Wilk test, Ti—initial test, Tf—final test, $\mathrm{n}$-number of subjects. 


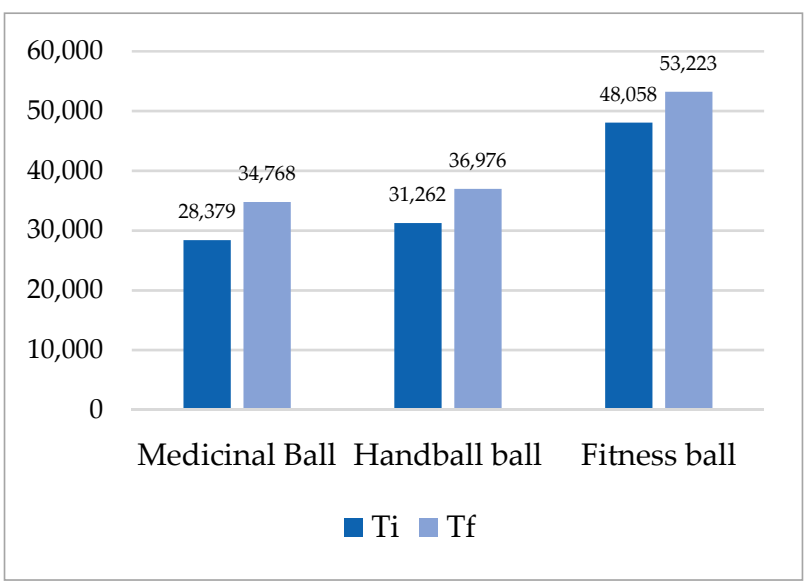

Figure 3. Mean of plank up test with 2 support points (arms, legs)—individual sports.

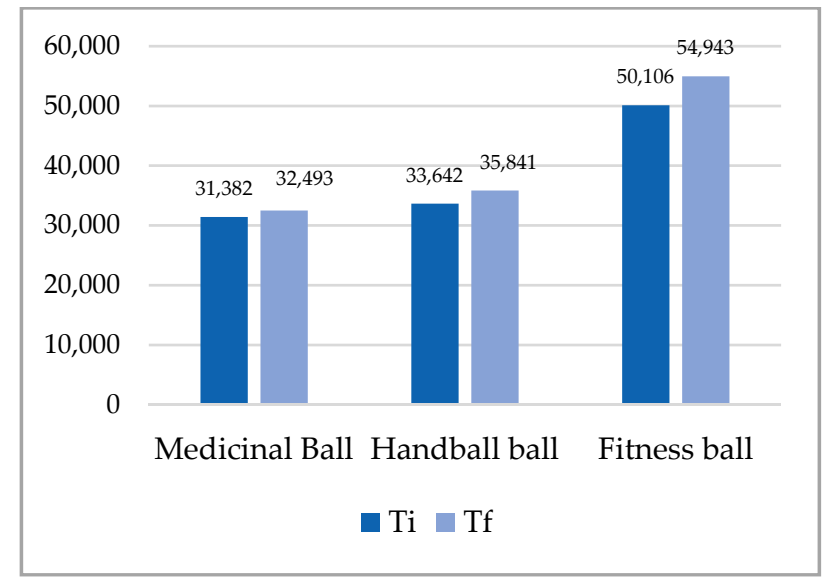

Figure 4. Mean of plank up test with 2 support points (arms, legs)-team sports.

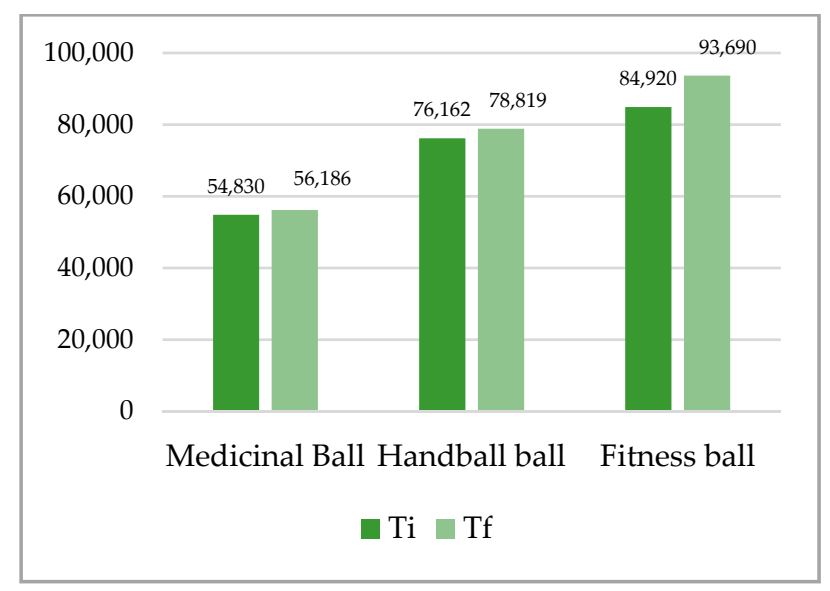

Figure 5. Mean of plank up test with 3 support points (arms, legs)—individual sports. 


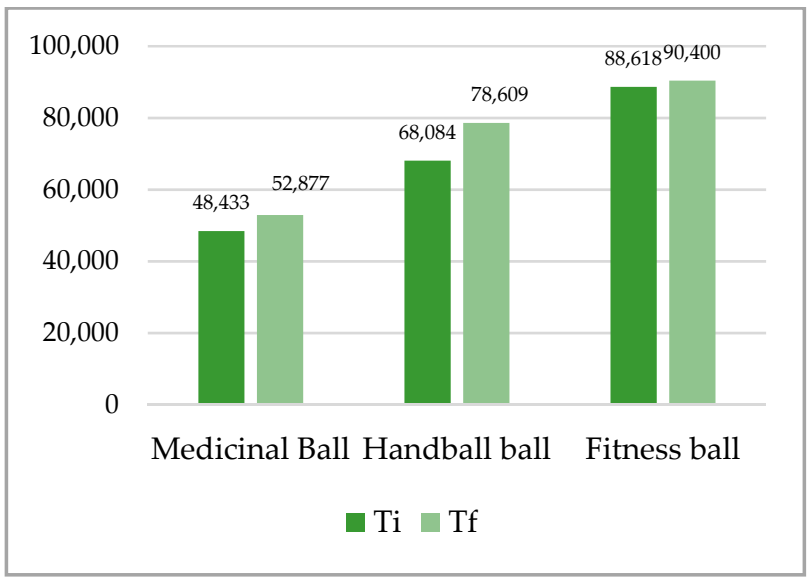

Figure 6. Mean of plank up test with 3 support points (arms, legs)—team sports.

The difference analyses between initial and final tests for maintaining balance show that the smallest differences were recorded for both groups on the medical balls, and the best results were recorded for the group of individual sport on the fitness ball DX 8.770, and for group of team sport on handball DX 10.524. The comparative analysis of the results shows a significant statistical power; the recorded values were higher than the threshold of 0.80 . The results were not statistically significant, with one exception for the up plank position with three support points (right arm, left arm, legs) on the handball ball for the team sports group (Table 4).

Table 4. Descriptive statistics of difference analyses between initial and final tests for maintaining balance test on the three types of ball in the up plank position-individual sports group and team sports group.

\begin{tabular}{|c|c|c|c|c|c|c|c|c|c|}
\hline Groups & Positions & Types of Balls & Tests & $X(s)$ & DX (s) & DSD & $t$ & $p$ & SP \\
\hline \multirow{6}{*}{$\begin{array}{l}\text { Individual } \\
\text { sports } \\
(22 \mathrm{n})\end{array}$} & \multirow{3}{*}{$\begin{array}{c}\text { Up plank position with } \\
2 \text { support points (arms, legs) }\end{array}$} & on the medical ball & $\begin{array}{l}\mathrm{Ti} \\
\mathrm{Tf}\end{array}$ & $\begin{array}{l}28.379 \\
34.768\end{array}$ & -6.389 & 14.921 & -1.962 & 0.064 & 0.876 \\
\hline & & on the handball ball & $\begin{array}{l}\mathrm{Ti} \\
\mathrm{Tf}\end{array}$ & $\begin{array}{l}31.262 \\
36.976\end{array}$ & -5.714 & 14.687 & -1.783 & 0.090 & 0.902 \\
\hline & & on the fitness ball & $\begin{array}{l}\mathrm{Ti} \\
\mathrm{Tf}\end{array}$ & $\begin{array}{l}48.058 \\
53.223\end{array}$ & -5.165 & 15.774 & -1.501 & 0.149 & 0.858 \\
\hline & \multirow{3}{*}{$\begin{array}{c}\text { Up plank position with } \\
3 \text { support points (right arm, } \\
\text { left arm, legs) }\end{array}$} & on the medical ball & $\begin{array}{l}\text { Ti } \\
\text { Tf }\end{array}$ & $\begin{array}{l}54.830 \\
56.186\end{array}$ & -1.355 & 5.470 & -1.136 & 0.269 & 0.802 \\
\hline & & on the handball ball & $\begin{array}{l}\mathrm{Ti} \\
\mathrm{Tf}\end{array}$ & $\begin{array}{l}76.162 \\
78.819\end{array}$ & -2.657 & 18.122 & -0.672 & 0.509 & 0.815 \\
\hline & & on the fitness ball & $\begin{array}{l}\mathrm{Ti} \\
\mathrm{Tf}\end{array}$ & $\begin{array}{l}84.920 \\
93.690\end{array}$ & -8.770 & 20.602 & -1.951 & 0.065 & 0.862 \\
\hline \multirow{6}{*}{$\begin{array}{l}\text { Team } \\
\text { sports } \\
(26 \mathrm{n})\end{array}$} & \multirow{3}{*}{$\begin{array}{l}\text { Up plank position with } 2 \\
\text { support points (arms, legs) }\end{array}$} & on the medical ball & $\begin{array}{l}\mathrm{Ti} \\
\mathrm{Tf}\end{array}$ & $\begin{array}{l}31.382 \\
32.493\end{array}$ & -1.111 & 5.773 & -1.000 & 0.327 & 0.807 \\
\hline & & on the handball ball & $\begin{array}{l}\mathrm{Ti} \\
\mathrm{Tf}\end{array}$ & $\begin{array}{l}33.642 \\
35.841\end{array}$ & -2.199 & 8.311 & -1.375 & 0.181 & 0.832 \\
\hline & & on the fitness ball & $\begin{array}{l}\mathrm{Ti} \\
\mathrm{Tf}\end{array}$ & $\begin{array}{l}50.106 \\
54.943\end{array}$ & -4.836 & 17.187 & -1.462 & 0.156 & 0.848 \\
\hline & \multirow{3}{*}{$\begin{array}{c}\text { Up plank position with } \\
3 \text { support points (right arm, } \\
\text { left arm, legs) }\end{array}$} & on the medical ball & $\begin{array}{l}\text { Ti } \\
\text { Tf }\end{array}$ & $\begin{array}{l}48.433 \\
52.877\end{array}$ & -4.444 & 11.875 & -1.945 & 0.063 & 0.836 \\
\hline & & on the handball ball & $\begin{array}{l}\mathrm{Ti} \\
\mathrm{Tf}\end{array}$ & $\begin{array}{l}68.084 \\
78.609\end{array}$ & -10.524 & 20.705 & -2.641 & 0.014 & 0.829 \\
\hline & & on the fitness ball & $\begin{array}{l}\mathrm{Ti} \\
\mathrm{Tf}\end{array}$ & $\begin{array}{l}88.618 \\
90.400\end{array}$ & -1.782 & 6.629 & -1.397 & 0.174 & 0.842 \\
\hline
\end{tabular}

X—mean, DX—differences of mean, DSD—differences in Std. Deviation, t-value of Student test, SP—statistical power, $\mathrm{p}$-level of probability, Ti-initial test, $\mathrm{Tf}$ - final test, $\mathrm{n}$-number of subjects. 
The results in Table 5, which analyzes the average differences recorded at the initial test between the individual sports group and group sports team, at both tests, show statistically insignificant differences, with one exception for the up plank position test with three support points (right arm, left arm, legs) on the medical ball. The comparative analysis of the results shows a significant statistical power; the recorded values were higher than the threshold of 0.80 , between 0.807 and 0.861 .

Table 5. Descriptive statistics for physical tests of maintaining balance on the three types of balls in the up plank position.

\begin{tabular}{|c|c|c|c|c|c|c|c|}
\hline Positions & Types of Balls & Tests & $X(s)$ & SD & $\mathbf{t}$ & $p$ & SP \\
\hline \multirow{6}{*}{$\begin{array}{l}\text { Up plank position with } 2 \text { support } \\
\text { points (arms, legs) }\end{array}$} & \multirow{2}{*}{ on the medical ball } & $\begin{array}{l}\text { Ti: individual } \\
\text { vs. team sports }\end{array}$ & -3.003 & 17.479 & -0.621 & 0.542 & 0.823 \\
\hline & & $\begin{array}{l}\text { Tf: individual } \\
\text { vs. team sports }\end{array}$ & 2.591 & 22.033 & 0.539 & 0.596 & 0.861 \\
\hline & \multirow{2}{*}{ on the handball ball } & $\begin{array}{l}\text { Ti: individual } \\
\text { vs. team sports }\end{array}$ & -1.102 & 24.522 & -0.206 & 0.839 & 0.826 \\
\hline & & $\begin{array}{l}\text { Tf: individual } \\
\text { vs. team sports }\end{array}$ & 1.783 & 32.325 & 0.253 & 0.803 & 0.849 \\
\hline & \multirow[t]{2}{*}{ on the fitness ball } & $\begin{array}{l}\text { Ti: individual } \\
\text { vs. team sports }\end{array}$ & 1.174 & 41.342 & 0.130 & 0.898 & 0.828 \\
\hline & & $\begin{array}{l}\text { Tf: individual } \\
\text { vs. team sports }\end{array}$ & 0.121 & 53.633 & 0.010 & 0.992 & 0.841 \\
\hline \multirow{6}{*}{$\begin{array}{l}\text { Up plank position with } 3 \text { support } \\
\text { points (right arm, left arm, legs) }\end{array}$} & \multirow{2}{*}{ on the medical ball } & $\begin{array}{l}\text { Ti: individual } \\
\text { vs. team sports }\end{array}$ & 5.982 & 12.946 & 2.118 & 0.047 & 0.847 \\
\hline & & $\begin{array}{l}\text { Tf: individual } \\
\text { vs. team sports }\end{array}$ & 1.624 & 17.709 & 0.420 & 0.679 & 0.818 \\
\hline & \multirow[t]{2}{*}{ on the handball ball } & $\begin{array}{l}\text { Ti: individual } \\
\text { vs. team sports }\end{array}$ & 7.611 & 42.180 & 0.827 & 0.418 & 0.852 \\
\hline & & $\begin{array}{l}\text { Tf: individual } \\
\text { vs. team sports }\end{array}$ & 4.271 & 47.728 & 0.410 & 0.686 & 0.819 \\
\hline & \multirow[t]{2}{*}{ on the fitness ball } & $\begin{array}{l}\text { Ti: individual } \\
\text { vs. team sports }\end{array}$ & 1.147 & 49.289 & 0.107 & 0.916 & 0.807 \\
\hline & & $\begin{array}{l}\text { Tf: individual } \\
\text { vs. team sports }\end{array}$ & 8.488 & 53.216 & 0.731 & 0.473 & 0.817 \\
\hline
\end{tabular}

X-Mean, SD—Std. Deviation, t—value of Student test, SP—statistical power, Ti-initial test, Tf—-final test, vs.—versus.

\section{Discussion}

The first aim of the study was to identify the differences regarding the static balance capacity in the up plank position on three different types of balls in terms of elasticity and degree of deformation. The results show significant differences in the static balance test in the up plank position on the three balls, in favor of the fitness ball, due to the superior elasticity and the higher degree of deformation compared to handball and medicinal balls. The spherical shape of the balls combine with the elasticity and the deformation capacity, determines the complex motor adaptation the subjects must perform in order to maintain their balance. The results of the study reflect that the shape and structure of the support surface significantly influences the static equilibrium capacity. The differences between the final and the initial testing reveal that the implementation of some balance exercise programs by using sports materials made of elastic materials and with spherical shapes were effective. The results of the study complement previous studies that have shown that maintaining the up plank position on different balls required the multimodal integration of sensory information, combined with postural and vestibular control on unstable surfaces [43-45].

The second aim was to investigate the differences in maintaining static balance on different balls between those who are practicing individual sports or team sports. The results of the study highlight the better static balance ability of subjects who practice team sports compared to those who practice individual sports. Highlighting the differences between the two categories of athletes in the study reflects the impact of differences in 
motor experience, the complexity of physical training, and the complexity of technical skills specific to team sports compared to the particularities of sports training in individual sports.

The results of the study are in agreement with the results of previous studies $[12,18,46,47]$, with the particularity that they aim to use the up plank position as an exercise to develop balance; in our study, this position was used both as an exercise and as a motor assessment test. Some studies have focused on studying the impact of the shape and technical characteristics of sports materials on physical performance [46,47], with a focus on the efficiency of motor and technical capacities $[48,49]$. The specialists in prophylaxis and physiotherapy focused on adapting the use of materials in the process of motor recovery and functional rehabilitation, depending on the technical characteristics and the individual and pathological particularities of the subjects [50-52]. The trend of using different sports and fitness materials is becoming increasingly obvious, and their area of use is increasingly extensive, including fitness centers and sport activities. The technical and compositional characteristics of these materials used can have major influences on physical capacity, perception of effort, body posture and vestibular and neuromotor rehabilitation. Consistent with the results of our study, previous studies have highlighted the influence of exercises performed on different fitness materials in order to improve static and dynamic balance [5,53-55]. The results of our study complete the research on the study of the up plank position, which were numerous and especially highlighted the anatomical, biomechanical and physical benefits of different categories of subjects actively involved in physical and sports activities [56-59], in the practice of fitness [55,60-63] and in prophylaxis [64-68].

Our study focused on evaluating the duration of maintaining the up plank position in conditions of static balance reduced to two and three points of support on balls that have spherical shapes, different characteristics of elasticity, and varying degrees of deformity. The results of our study were statistically significant in the case of evaluating the entire sample. Regarding the comparison of the individual sports group with the team sports group, it was highlighted that those from team sports have superior indices of balance and superior strength, revealed by the period of maintenance of balance on duration of all the tests and on all three variants of balls. The results of the study contribute to the understanding of the effects on human physical capacity and of the exercise modalities determined by the technical characteristics of sports materials in physical activities and those of prophylactic activities.

The practical implications of the study will be focused on the use of balls of various sizes and with different technical characteristics in order to improve the static balance. We recommend the use of balls with a high elasticity characteristic, especially in the first phase of exercise or prophylaxis, then continue with balls with lower elastic characteristics and low degrees of deformation that require increased fitness skills. Exercises on balls to improve static balance are recommended for all categories of athletes, mainly for practitioners of complex sports that involve balance skills, such as gymnastics, aerobics and fitness.

The main strengths of this study are the relatively large number of participants who met the inclusion criteria, and the number of tests performed in the up plank position with the reduction in the support surface to two and three points on three balls with the same circumference, but with different elastic characteristics, different deformation capacities and different weights. The results may be relevant in both the practice of physical activities in order to improve motor control, postural control and to improve static balance and general muscle strength. The limits of the identification research are the period of study was limited because of changes in the educational system from partial onside into total online, non-identification of the degree of muscular tension in performing the tests for highlighting the most activated muscle groups when maintaining the up plank position, and the non-involvement of a sample of student girls, due to the small number of total students in the academic program targeted in the research. 


\section{Conclusions}

The results of the study confirm that a higher elasticity of the balls positively influences the results regarding the physical performances, aiming at a static balance in the up plank position. The results of the balance test on the fitness ball with two and three support points were superior to those recorded in the tests on handball and medical balls. The superior results registered at the tests on the handball and fitness balls are considered to be determined by the superior characteristics of elasticity and, implicitly, its deformation, in comparison with the medical balls that have a reduced elasticity. The results recorded by the study subjects reflect the fact that, on the medical ball, the perception of balance is better than on the handball and fitness balls, which are more elastic and easier, and therefore have greater possibilities of deformation, and the joint and muscle demand is higher. The study shows that students playing team games showed a greater capacity for static balance on spherical and elastic surfaces than those who practice individual sports. These results could have practical connotations regarding the extension of exercise programs to improve balance by using fitness materials which are as varied as possible and with characteristics of elasticity, shape, hardness, etc., that are as diverse as possible. The results of athletes playing team games compared to those in individual sports can be correlated with the greater complexity of technical training, which can have a positive influence on the level of body balance. The relevance of the research results from the possibility of using different balls in conditions of positioning and body posture with a diminished support base in order to improve physical fitness focused on functional, vestibular and neuromuscular prophylaxy and rehabilitations.

Author Contributions: Conceptualization, D.B., A.B., G.M., M.I.E., A.N., V.T.G., V.T., R.S., R.M. and L.M.; methodology, D.B., A.B., G.M., M.I.E., A.N., V.T.G., V.T., R.S., R.M. and L.M.; software, D.B., A.B., G.M., M.I.E., A.N., V.T.G., V.T., R.S., R.M. and L.M.; validation, D.B., A.B., G.M., M.I.E., A.N., V.T.G., V.T., R.S., R.M. and L.M.; formal analysis, D.B., A.B., G.M., M.I.E., A.N., V.T.G., V.T., R.S., R.M. and L.M.; investigation, D.B., A.B., G.M., M.I.E., A.N., V.T.G., V.T., R.S., R.M. and L.M.; resources, D.B., A.B., G.M., M.I.E., A.N., V.T.G., V.T., R.S., R.M. and L.M.; data curation, D.B., A.B., G.M., M.I.E., A.N., V.T.G., V.T., R.S., R.M. and L.M.; writing—original draft preparation, D.B., A.B., G.M., M.I.E., A.N., V.T.G., V.T., R.S., R.M. and L.M.; writing-review and editing, D.B., A.B., G.M., M.I.E., A.N., V.T.G., V.T., R.S., R.M. and L.M.; visualization, D.B., A.B., G.M., M.I.E., A.N., V.T.G., V.T., R.S., R.M. and L.M.; supervision, D.B., A.B., G.M., M.I.E., A.N., V.T.G., V.T., R.S., R.M. and L.M. All authors have read and agreed to the published version of the manuscript.

Funding: This research received no external funding.

Institutional Review Board Statement: The study was conducted according to the guidelines of the Declaration of Helsinki and approved by the Review Board of Movement Sciences Department, "George Emil Palade" University of Medicine, Pharmacy, Sciences and Technology of Targu Mures, Romania (resolution no. 36/23/05/2019).

Informed Consent Statement: Not applicable.

Data Availability Statement: Not applicable.

Conflicts of Interest: The authors declare no conflict of interest.

\section{References}

1. Craciunescu, O.; Lungu, M.; Zarnescu, O.; Gaspar, A.; Moldovan, L. Polyurethane-based materials covered with natural polymers for medical applications. Mater. Plast. 2008, 45, 163-166.

2. Dusa, F.S.; Badau, A.; Badau, D.; Trambitas, C.; Brinzaniuc, K. Investigating the deformation parameters of PVC fitness balls in relation to the height and body mass index of the users. Mater. Plast. 2017, 54, 606-609. [CrossRef]

3. Badau, A.; Badau, D.; Enoiu, R.S. Evaluation of stable balance capacity by using bosu ball surfaces on different pressure levels. Mater. Plast. 2019, 56, 216-219. [CrossRef]

4. Micarelli, A.; Viziano, A.; Granito, I.; Micarelli, R.X.; Felicioni, A.; Alessandrini, M. Changes in body composition in unilateral vestibular hypofunction: Relationships between bioelectrical impedance analysis and neuro-otological parameters. Eur. Arch. Oto-Rhino. Laryngol. 2021, 1-9. [CrossRef] 
5. Schedler, S.; Tenelsen, F.; Wich, L.; Muehlbauer, T. Effects of balance training on balance performance in youth: Role of training difficulty. BMC Sports Sci. Med. Rehabilit. 2020, 12, 1-10. [CrossRef]

6. Muhlfay, G.; Fabian, Z.; Neagoe, R.; Horvath, K.U. Applications of 3D planning, plastic materials and additive manufacturing in functional rehabilitations in the head and neck surgery. Mater. Plast. 2018, 55, 431-433. [CrossRef]

7. Rogers, M.W.; Mille, M.-L. Balance perturbations. Handb. Clin. Neurol. 2018, 159, 85-105.

8. Paillard, T. Plasticity of the postural function to sport and/or motor experience. Neurosci. Biobehav. Rev. 2017, 72, 129-152. [CrossRef] [PubMed]

9. Seidel, O.; Carius, D.; Kenville, R.; Ragert, P. Motor learning in a complex balance task and associated neuroplasticity: A comparison between endurance athletes and nonathletes. J. Neurophysiol. 2017, 118, 1849-1860. [CrossRef] [PubMed]

10. Raicea, V.; Kovacs, J.; Moraru, L.; Suciu, H. Coronary sinus lactate as marker of myocardial ischemia in cardiac surgery: Correlation with morbidity and mortality after cardiac surgery/Lactatul din sinusul coronarian-marker al ischemiei miocardice în chirurgia cardiacă: Corelaţii cu morbiditatea şI mortalitatea postoperatorie. Rev. Romana Med. Lab. 2015, 23, 189-197. [CrossRef]

11. Halmaciu, I.; Suciu, B.A.; Trambitas, C.; Vunvulea, V.; Ivanescu, A.; Clipa, A.; Adascalitei, P.; Brinzaniuc, K.; Fodor, D. It is useful to use plastic anatomical models in teaching human anatomy? Mater. Plast. 2018, 55, 414-418. [CrossRef]

12. Sarto, F.; Cona, G.; Chiossi, F.; Paoli, A.; Bisiacchi, P.; Patron, E.; Marcolin, G. Dual-tasking effects on static and dynamic postural balance performance: A comparison between endurance and team sport athletes. Peer] 2020, 8, e9765. [CrossRef]

13. Paillard, T. Relationship between sport expertise and postural skills. Front. Psychol. 2019, 10. [CrossRef]

14. Zemková, E. Sport-specific balance. Sports Med. 2014, 44, 579-590. [CrossRef] [PubMed]

15. De La Torre, J.; Marin, J.; Polo, M.; Marín, J.J. Applying the minimal detectable change of a static and dynamic balance test using a portable stabilometric platform to individually assess patients with balance disorders. Healthcare 2020, 8, 402. [CrossRef]

16. Vaičienè, G.; Berškienè, K.; Slapsinskaite, A.; Mauricienė, V.; Razon, S. Not only static: Stabilization manoeuvres in dynamic exercises - A pilot study. PLoS ONE 2018, 13, e0201017. [CrossRef]

17. Carter, J.M.; Beam, W.C.; Mcmahan, S.G.; Barr, M.L.; Brown, L.E. The effects of stability ball training on spinal stability in sedentary individuals. J. Strength Cond. Res. 2006, 20, 429-435. [CrossRef]

18. Yu, W.; Cha, S.; Seo, S. The effect of ball exercise on the balance ability of young adults. J. Phys. Ther. Sci. 2017, 29, 2087-2089. [CrossRef] [PubMed]

19. Siegel, D. Effects of medicine ball training in fitness performance of high school physical education students. J. Phys. Educ. Recreat. Dance 2008, 79, 9. [CrossRef]

20. Caballero, C.; Barbado, D.; Urbán, T.; García-Herrero, J.A.; Moreno, F.J. Functional variability in team-handball players during balance is revealed by non-linear measures and is related to age and expertise level. Entropy 2020, 22, 822. [CrossRef] [PubMed]

21. Sekendiz, B.; Cug, M.; Korkusuz, F. Effects of Swiss-ball core strength training on strength, endurance, flexibility, and balance in sedentary women. J. Strength Cond. Res. 2010, 24, 3032-3040. [CrossRef]

22. Willardson, J.M. Core stability training: Applications to sports conditioning programs. J. Strength Cond. Res. 2007, 21, 979-985. [CrossRef]

23. Suciu, B.A.; Gurzu, S.; Marginean, L.; Milutin, D.; Halmaciu, I.; Jung, I.; Branzaniuc, K.; Molnar, C. Significant shrinkage of multifocal liver metastases and long-term survival in a patient with rectal cancer, after trans-arterial chemoembolization (TACE). Medicine 2015, 94, e1848. [CrossRef]

24. Suciu, B.A.; Halmaciu, I.; Bud, V.; Copotoiu, C.; Fodor, D.R.P.; Trambitas, C.; Vunvulea, V.; Molnar, C.; Brinzaniuc, K. Using polypropylene for bronchial stump closure after pulmonary resections. Mater. Plast. 2017, 54, 520-522. [CrossRef]

25. Ciobotaru, V.; Socolescu, A.M. Caracterizarea unor condensate salicilformaldehidaminice. Mater. Plast. 2008, 45, $236-240$.

26. Burgaz, E.; Gencoglu, O.; Goksuzoglu, M. Ondokuz Mayis University Carbon black reinforced natural rubber/butadiene rubber and natural rubber/butadiene rubber/styrene-butadiene rubber composites: Part II. Dynamic mechanical properties and fatigue behavior. Res. Eng. Struct. Mater. 2019, 5, 1-13. [CrossRef]

27. Oprea, S.; Potolinca, O. Synthesis and characterization of polyurethane elastomers based on 4,5-dibromofluorescein and various crosslinkers. Mater. Plast. 2009, 6, 408-412.

28. Gradinaru, L.M.; Vlad, S.; Drobota, M.; Spiridon, M.; Istrate, I. A Facile Activation Method for Improving the Wettability of Polyurethane Surfaces. Mater. Plast. 2019, 56, 416-420. [CrossRef]

29. Ahmed, R.M.; Ibrahiem, A.A.; El-Bayoumi, A.S.; Atta, M.M. Structural, mechanical, and dielectric properties of polyvinylchloride/graphene nano platelets composites. Int. J. Polym. Anal. Charact. 2021, 26, 68-83. [CrossRef]

30. Neto, C.F.; Neto, G.R.; Araújo, A.T.; Sousa, M.S.C.; Sousa, J.B.C.; Batista, G.R.; Reis, V.M.M.R. Can programmed or self-selected physical activity affect physical fitness of adolescents? J. Hum. Kinet. 2014, 43, 125-130. [CrossRef]

31. Dos S Andrade, M.; Fachina, R.J.; Cruz, W.; Benedito-Silva, A.A.; Da Silva, A.C.; De Lira, C.A. Strength field tests performance are correlated with isokinetic strength of shoulder rotator muscles in female handball players. J. Sports Med. Phys. Fit. 2014, 54, 403-409.

32. Ia, A.R. Effects of center of mass kinematics on ball velocity during jump throwing in handball. MOJ Appl. Bionics Biomech. 2018, 2, 1. [CrossRef]

33. Badau, D.; Badau, A. Identifying the incidence of exercise dependence attitudes, levels of body perception, and preferences for use of fitness technology monitoring. Int. J. Environ. Res. Public Health 2018, 15, 2614. [CrossRef] 
34. Jankauskiene, R.; Baceviciene, M.; Pajaujiene, S.; Badau, D. Are adolescent body image concerns associated with healthcompromising physical activity behaviours? Int. J. Environ. Res. Public Health 2019, 16, 1225. [CrossRef] [PubMed]

35. Ene-Voiculescu, V.; Ene-Voiculescu, C.; Abramiuc, A. Current selection procedures in the naval pentathlon. Mircea cel Batran Naval Academy Scientific Bulletin 2017, 20, 420-422.

36. Ene-Voiculescu, V.; Ene-Voiculescu, C. Psychomotricity: The body as self-expression. Mircea cel Batran Naval Acad. Sci. Bull. 2018, 21, 1-6.

37. Nicola, P.; Ardeleanu, E.; Strat, L.; Baaj, T.; Gurgus, D.; Gadau, C.; Dorobantu, M.; Darabont, R.; Tilea, I.; Varga, A.; et al. Evaluation of biochemical and clinical parameters of hypertension with type 2 diabetes mellitus. Rev. Chim. 2018, 69, $2402-2406$. [CrossRef]

38. Omboni, S.; Posokhov, I.; Parati, G.; Rogoza, A.; Kotovskaya, Y.; Arystan, A.; Avolio, A.; Barkan, V.; Bulanova, N.; Muñoz, E.C.; et al. Ambulatory blood pressure and arterial stiffness web-based telemonitoring in patients at cardiovascular risk. First results of the VASOTENS (Vascular health ASsessment Of The hypertensive patients) Registry. J. Clin. Hypertens. 2019, 21, 1155-1168. [CrossRef] [PubMed]

39. O'Keeffe, B.T.; MacDonncha, C.; Donnelly, A.E. Students' attitudes towards and experiences of the Youth-fit health-related fitness test battery. Eur. Phys. Educ. Rev. 2021, 27, 41-56. [CrossRef]

40. Liebenson, C. Plank to push-up. J. Bodyw. Mov. Ther. 2016, 20, 937-938. [CrossRef]

41. Tong, T.K.; Wu, S.; Nie, J. Sport-specific endurance plank test for evaluation of global core muscle function. Phys. Ther. Sport 2014, 15, 58-63. [CrossRef] [PubMed]

42. Strand, S.L.; Hjelm, J.; Shoepe, T.C.; Fajardo, M.A. Norms for an isometric muscle endurance test. J. Hum. Kinet. 2014, 40, 93-102. [CrossRef]

43. Oliva-Lozano, J.M.; Muyor, J.M. Core muscle activity during physical fitness exercises: A systematic review. Int. J. Environ. Res. Public Health 2020, 17, 4306. [CrossRef] [PubMed]

44. Escamilla, R.F.; Lewis, C.; Pecson, A.; Imamura, R.; Andrews, J.R. Muscle activation among supine, prone, and side position exercises with and without a Swiss ball. Sports Health. Multidiscip. Approach 2016, 8, 372-379. [CrossRef] [PubMed]

45. Tsuruike, M.; Munson, M.; Hirose, N.; Nishime, R.S. Core stability muscle activity during standing lower body twisting exercises. Int. J. Sports Phys. Ther. 2020, 15, 1052-1060. [CrossRef] [PubMed]

46. Ferrer, N.P.; Santelices, O.Y.; Maghanoy, M.N.; Wisdom Valleser, C. Comparative analysis of the table tennis plastic ball and celluloid ball in terms of racket angle. In Proceedings of the 15th ITTF Sports Science Congress, Düsseldorf, Germany, 27-28 May 2017; pp. 131-143.

47. Ismail, K.A.; Stronge, W. Viscoplastic analysis for direct impact of sports balls. Int. J. Non Linear Mech. 2012, 47, 16-21. [CrossRef]

48. Yang, C.; Luo, N.; Cui, Q.; Chen, H.; Gao, Q.; Liang, M.; Zhou, S.; Yu, Q.; Zhang, J.; Zhang, M.; et al. Altered brain functional connectivity density in fast-ball sports athletes with early stage of motor training. Front. Psychol. 2020, 11. [CrossRef]

49. Buszard, T.; Reid, M.; Masters, R.; Farrow, D. Scaling the equipment and play area in children's sport to improve motor skill acquisition: A systematic review. Sports Med. 2016, 46, 829-843. [CrossRef]

50. León-Quismondo, J.; García-Unanue, J.; Burillo, P. Best practices for fitness center business sustainability: A qualitative vision. Sustainability 2020, 12, 5067. [CrossRef]

51. Thompson, P.D.; Baggish, A.L.; Franklin, B.; Jaworski, C.; Riebe, D. American College of sports medicine expert consensus statement to update recommendations for screening, staffing, and emergency policies to prevent cardiovascular events at health fitness facilities. Curr. Sports Med. Rep. 2020, 19, 223-231. [CrossRef]

52. Gallo, P.M. A health fitness professional, group exercise instructor, and clinical exercise physiologist walk into a fitness facility. ACSM Health Fit. J. 2020, 24, 40-42. [CrossRef]

53. Doria, M.; Nalebuff, B. Measuring competitive balance in sports. J. Quant. Anal. Sports. 2021, 17, 29-46. [CrossRef]

54. Sember, V.; Grošelj, J.; Pajek, M. Balance tests in pre-adolescent children: Retest reliability, construct validity, and relative ability. Int. J. Environ. Res. Public Health 2020, 17, 5474. [CrossRef]

55. Nepocatych, S.; Ketcham, C.J.; Vallabhajosula, S.; Balilionis, G. The effects of unstable surface balance training on postural sway, stability, functional ability and flexibility in women. J. Sports Med. Phys. Fit. 2016, 58, 27-34.

56. Kaewkannate, K.; Kim, S. A comparison of wearable fitness devices. BMC Public Health 2016, 16, 1-16. [CrossRef]

57. Alfrey, L.; Gard, M. Figuring out the prevalence of fitness testing in physical education: A figurational analysis. Eur. Phys. Educ. Rev. 2019, 25, 187-202. [CrossRef]

58. Cavaggioni, L.; Ongaro, L.; Zannin, E.; Iaia, F.M.; Alberti, G. Effects of different core exercises on respiratory parameters and abdominal strength. J. Phys. Ther. Sci. 2015, 27, 3249-3253. [CrossRef]

59. Ervin, R.B.; Fryar, C.D.; Wang, C.-Y.; Miller, I.M.; Ogden, C.L. Strength and body weight in US children and adolescents. Pediatrics 2014, 134, e782-e789. [CrossRef]

60. Sylvia, L.G.; Bernstein, E.E.; Hubbard, J.L.; Keating, L.; Anderson, E.J. Practical guide to measuring physical activity. J. Acad. Nutr. Diet. 2014, 114, 199-208. [CrossRef]

61. Araújo, L.S.; Wasley, D.; Redding, E.; Atkins, L.; Perkins, R.; Ginsborg, J.; Williamon, A. Fit to perform: A profile of higher education music students' physical fitness. Front. Psychol. 2020, 11. [CrossRef] 
62. Osipov, A.; Ratmanskaya, T.; Nagovitsyn, R.; Zhuikova, S.; Iermakov, S. Increasing the level of cardiorespiratory and strength endurance of female students by means of mixed training (Kangoo-jumps fitness and resistance training). Phys. Act. Rev. 2020, 8, 38-47. [CrossRef]

63. Liu, F.; Jones, A.; Evans, K.; Tsang, R.; Ao, L.M. Trunk muscle endurance in Chinese adults. J. Back Musculoskelet. Rehabil. 2018, 31, 593-602. [CrossRef]

64. Calatayud, J.; Escriche-Escuder, A.; Cruz-Montecinos, C.; Andersen, L.L.; Pérez-Alenda, S.; Aiguadé, R.; Casaña, J.; Escuder, E.; Montecinos, C.; Alenda, P. Tolerability and muscle activity of core muscle exercises in chronic low-back pain. Int. J. Environ. Res. Public Health 2019, 16, 3509. [CrossRef] [PubMed]

65. Calatayud, J.; Casaña, J.; Martín, F.; Jakobsen, M.D.; Andersen, L.L.; Colado, J.C. Electromyographic effect of using different attentional foci during the front plank exercise. Am. J. Phys. Med. Rehabil. 2019, 98, 26-29. [CrossRef] [PubMed]

66. Talaghir, L.; Mocanu, G.; Iconomescu, T.; Mindrescu, V. Development of speed manifestation forms during physical education classes at university. Human. Sport. Med. 2018, 18, 95-102. [CrossRef]

67. De Paulo, T.R.S.; Winters-Stone, K.M.; Viezel, J.; Rossi, F.E.; Aro, B.L.; Trindade, A.C.A.C.; Codogno, J.S.; Junior, I.F.F. Comparing exercise responses to aerobic plus resistance training between postmenopausal breast cancer survivors undergoing aromatase inhibitor therapy and healthy women. Disabil. Rehabilit. 2018, 41, 2175-2182. [CrossRef]

68. Blasimann, A.; Eberle, S.; Scuderi, M. Effekt eines Rumpfkräftigungsprogramms (inklusive Unterarm- und seitlichem Unterarmstütz) auf die Verletzungsrate von erwachsenen Fußballspielern: Eine systematische Literaturübersicht. Sportverletz. Sportschaden 2018, 32, 35-46. [CrossRef] [PubMed] 